Maciej Koszowski

Wyższa Szkoła Biznesu, Dąbrowa Górnicza

\title{
Oczekiwania konsumentów odnośnie do oferowanych im towarów oparte na zapewnieniach publicznych pochodzących od sprzedawcy, producenta, osoby, która się za producenta podaje, importera i dystrybutora towaru oraz ich przedstawicieli
}

DOI: http://dx.doi.org/10.12775/SIT.2013.007

\section{Wprowadzenie}

Ustawa z dnia 27 lipca 2002 r. o szczególnych warunkach sprzedaży konsumenckiej oraz zmianie Kodeksu cywilnego (Dz.U. z 2002 r. $\mathrm{Nr}$ 141, poz. 1176 wraz z późniejszymi zmianami) ${ }^{1}$ w art. 4 ust. 3 zd. 2 nakazuje domniemywać zgodność towaru konsumpcyjnego $\mathrm{z}$ umową, jeśli towar ten odpowiada oczekiwaniom dotyczącym towaru tego rodzaju, opartym na składanych publicznie zapewnie-

${ }^{1}$ Dla uproszczenia zw. dalej „ustawą o sprzedaży konsumenckiej”. Odnośnie do oceny rozwiązań prawnych przewidzianych w tej ustawie zob. M. Koszowski, Ocena rozwiazzań prawnych zawartych $w$ ustawie o szczególnych warunkach sprzedaży konsumenckiej oraz zmianie Kodeksu cywilnego implementującej dyrektywę Parlamentu Europejskiego i Rady nr 1999/44/WE, „Przegląd Sądowy” 2013, nr 6, s. 9-28. 
niach sprzedawcy, producenta lub jego przedstawiciela; przy czym szczególnie istotne mają być te $z$ zapewnienia, jakie, odnosząc się do właściwości towaru (w tym terminu, w jakim ma on je zachować), zostały wyrażone w jego oznakowaniu lub reklamie. Podobną regulację zawiera dyrektywa Parlamentu Europejskiego i Rady nr 1999/44/ /WE ${ }^{2}$ : mianowicie zgodnie $z$ jej art. 2 ust. 2 lit. d domniemywa się, że towary konsumpcyjne są zgodne $z$ umową, jeżeli wykazują jakość i wykonanie, które są normalne dla towarów tego samego rodzaju i jakich konsument może racjonalnie oczekiwać, biorąc pod uwagę charakter tych towarów oraz wszelkie oświadczenia publiczne na temat ich szczególnych właściwości, wygłoszone przez sprzedawcę, producenta lub ich przedstawicieli, w tym przede wszystkim w reklamie lub na etykiecie. Pojęcia publicznych zapewnień (oświadczeń) nie znajdziemy natomiast w uchodzącej za pierwowzór dyrektywy Konwencji Narodów Zjednoczonych o umowach międzynarodowej sprzedaży towarów ${ }^{3}$.

W efekcie też regulacja zawarta w dyrektywie wydaje się być nowocześniejsza, tj. lepiej dostosowana do warunków, w jakich obecnie dokonuje się sprzedaż, tym bardziej jeszcze ta, w której po stronie kupujących występują konsumenci. Ci ostatni, podejmując decyzję o zakupie, nader często kierują się bowiem zawartością wszelkiego rodzaju materiałów reklamowych i innych pochodzących od producenta/dystrybutora towaru wiadomości, nie mając przy tym zbyt dużych, jeśli jakichkolwiek, możliwości zweryfikowania prawdziwości (rzetelności) zawartych tam informacji ${ }^{4}$. Nie sposób byłoby również oczekiwać od przeciętnego konsumenta takiego stopnia

${ }^{2}$ Dyrektywa Parlamentu Europejskiego i Rady nr 1999/44/WE z dnia 25 maja 1999 r. w sprawie niektórych aspektów sprzedaży towarów konsumpcyjnych i związanych z tym gwarancji (Dz.Urz. WE L 171, z 7 lipca 1999 r.), zw. dalej „dyrektywą”.

${ }^{3}$ Konwencja Narodów Zjednoczonych o umowach międzynarodowej sprzedaży towarów, sporządzona w Wiedniu dnia 11 kwietnia 1980 r., ratyfikowana przez Polskę w dniu 13 marca 1995 r. (Dz.U. z 1997 r. Nr 45, poz. 286), w stosunku do której weszła w życie z dniem 1 czerwca 1996 roku.

${ }^{4}$ Na okoliczność, iż nowoczesne media umożliwiają oraz zachęcają do podejmowania rzeczywistej decyzji o nabyciu towaru nie w sklepie, lecz w trakcie oglądania telewizji albo podczas surfowania w Internecie, zwraca uwage S. Grundmann, Consumer Law, Commercial Law, Private Law: How can the 
staranności i takiej wiedzy fachowej, jakich można się spodziewać w przypadku kupujących będących profesjonalistami.

Notabene także na tle instytucji rękojmi za wady rzeczy sprzedanej w literaturze przedmiotu można spotkać głosy obarczające sprzedawcę odpowiedzialnością za zawartość złożonych publicznie przez producenta (dystrybutora) zapewnień, zwłaszcza tych znajdujących się na rzeczy, jej opakowaniu, dołączonych do niej dokumentach tudzież wyrażonych w jej reklamie. Mianowicie, zapewnienia takie, drogą wykładni rozszerzającej przepisu $\mathrm{z}$ art. 556 $\S 1$ k.c., próbuje się zrównywać z zapewnieniami, jakie odnośnie do właściwości przez rzecz posiadanych poczynił sprzedawca; a tym samym nieodpowiadanie przez rzecz, jaka została wydana kupującemu, takim zapewnieniom kwalifikować jako jedną $z$ postaci wady fizycznej ${ }^{5}$.

\section{Zapewnienia publiczne}

\subsection{Przedmiot}

Przedmiotem publicznych zapewnień może być zarówno posiadanie przez towar określonych właściwości, jak i jego przydatność do poszczególnych celów ${ }^{6}$. Właściwości i cele, o jakich tu mowa, winny

Sales Directive and the Sales Convention be so Similar?, "European Business Law Review” 2003, t. 14, nr 3, s. 240-241.

5 Zob. W. Katner, w: Prawo Umów Handlowych, red. S. Włodyka, wyd. 2, seria System Prawa Handlowego, Warszawa 2006, s. 1000; C. Żuławska, w: Komentarz do kodeksu cywilnego. Księga trzecia. Zobowiazania, t. 2, red. G. Bieniek, wyd. 9, Warszawa 2009, s. 59; E. Habryn-Motawska, Niezgodność towaru konsumpcyjnego z umowa sprzedaży konsumenckiej, Warszawa 2010, s. $80,128-129$.

${ }^{6}$ Tak też E. Habryn-Motawska, op.cit., s. 78-79, 80. Sposób zredagowania przepisu $z$ art. 4 ust. 3 zd. 2 ustawy o sprzedaży konsumenckiej, podobnie jak i przepisu $z$ art. 2 ust. 2 lit. d dyrektywy, mógłby sugerować, że prawnie relewantne są tylko publiczne zapewnienia, jakie odnoszą się do właściwości towaru. W świetle całości unormowań z tej ustawy/dyrektywy takie ograniczenie przedmiotu publicznych zapewnień nie wydaje się jednak w żaden sposób uzasadnione. 
być jednak ponadprzeciętne (szczególne, specyficzne), tzn. powinny one odbiegać na korzyść od właściwości typowych (standardowych) dla towarów danego rodzaju oraz od celów, do jakich towary danego rodzaju są zwykle używane (wykraczać poza zakres zwykłego użytku takich towarów) ${ }^{7}$. O tym, że zapewnienia (oświadczenia) publiczne mają być „na temat szczególnych właściwości towarów”, explicite stanowi art. 2 ust. 2 lit. d dyrektywy.

W konsekwencji przez zapewnienie w znaczeniu ustawy o sprzedaży konsumenckiej (oświadczenie w znaczeniu dyrektywy) będziemy rozumieć każdą wypowiedź, $z$ jakiej wynika - choćby w sposób pozwalający się tego domyślić - że towar odznacza się jakąś szczególną właściwością lub jest zdatny do jakiegoś szczególnego celu. Za takie zapewnienie (oświadczenie) nie będzie mogło natomiast uchodzić samo jedynie ogólnikowe zachwalanie towaru, np. przez użycie takich określeń jak „świetny, „doskonały”, „wspaniały”, „cudowny”.

\subsection{Publiczny charakter}

Zapewnienia, o których mowa jest w art. 4 ust. 3 zd. 2 ustawy o sprzedaży konsumenckiej, muszą być zapewnieniami złożonymi publicznie. Oznacza to, że do ich złożenia powinno dojść w taki sposób, by z ich zawartością mogła zapoznać się bliżej nieokreślona liczba osób ${ }^{9}$. Nie ma natomiast przeszkód, aby grono potencjalnych

7 Na to, że „Z zapewnienia o właściwości towaru można wnosić i o innych jego właściwościach lub zdatności do celu innego (bądź także innego) niż zwykły cel użytkowy”, wskazuje M. Pecyna, Ustawa o sprzedaży konsumenckiej. Komentarz, wyd. 2, Warszawa 2007, s. 136. Odnośnie do instytucji, jaką jest zwykły użytek i typowe (standardowe) właściwości towarów danego rodzaju, na tle sprzedaży konsumenckiej zob. M. Koszowski, Zwykły użytek oraz typowe właściwości $w$ przypadku towarów konsumpcyjnych, „Przegląd Ustawodawstwa Gospodarczego" 2013, nr 1, s. 24-30.

8 Zob. też E. Habryn-Motawska, op.cit., s. 79 i S. Grundmann, w: EU Sales Directive. Commentary, red. M.C. Bianca i S. Grundmann, Antwerpia 2002, s. 138 .

${ }_{9}$ Zob. E. Wieczorek, Sprzedaż konsumencka. Komentarz do ustawy, Gdańsk 2005, s. 50, E. Habryn-Motawska, op.cit., s. 79, J. Jezioro, w: Ustawa o szczególnych warunkach sprzedaży konsumenckiej. Komentarz, red. J. Jezioro, War- 
odbiorców było zawężone tylko do podmiotów pewnej kategorii (dzieci, kobiet, narciarzy, prawników, gospodyń domowych itd.) ${ }^{10}$; dokładna liczba osób, które faktycznie dowiedzą się o treści zapewnienia, nigdy nie może być jednak z góry wiadoma.

\subsection{Sposób złożenia}

Zasadniczo sposób, w jaki może dojść do złożenia zapewnienia publicznego, pozostaje dowolny ${ }^{11}$. Przede wszystkim mogą zostać tutaj użyte środki masowego przekazu, jak: telewizja, radio, prasa, Internet, w tym wiadomości rozsyłane pocztą elektroniczną do nieoznaczonych adresatów (tzw. mailing, a nawet spam). Złożenie zapewnienia o charakterze publicznym może się jednak odbyć i inaczej, tj. np. przez wywieszenie w miejscu publicznie dostępnym wszelkiego rodzaju ogłoszeń, plakatów, ulotek itp. albo wrzucanie do tradycyjnych skrzynek pocztowych niezaadresowanych materiałów reklamowych i promocyjnych ${ }^{12}$.

W konsekwencji do kategorii zapewnień publicznych trzeba by także zaliczyć udostępnione nieoznaczonemu kręgowi osób próbki i wzory oraz opisy towarów konsumpcyjnych (jakie zawarte są np. w przeznaczonych dla ogółu folderach, katalogach, informatorach, gazetach, kartach gwarancyjnych, instrukcjach obsługi (montażu) i innych tego typu dokumentach) ${ }^{13}$; i to nawet wówczas, gdy takie

szawa 2010, s. 178; J. Szczotka, Sprzedaż konsumencka. Komentarz, wyd. 2, Lublin 2007, s. 62 oraz M. Pecyna, op.cit., s. 138. Nieco bardziej restrykcyjne podejście - tj. iż medium użyte do złożenia publicznego zapewnienia (oświadczenia) winno być tego rodzaju, ażeby sprzedawca mógł się z tym zapewnieniem (oświadczeniem) zapoznać - na tle art. 2 ust. 2 lit. d dyrektywy prezentuje S. Grundmann, w: EU Sales, s. 139.

${ }^{10} \mathrm{~W}$ kontekście zapewnień publicznych o możliwości zawężenia grona adresatów za pomocą kryterium „płci, wieku, zainteresowań, wiedzy, umiejętności itp.” wspomina J. Szczotka, op.cit., s. 62.

${ }^{11}$ E. Wieczorek, op.cit., s. 50; J. Pisuliński, w: System Prawa Prywatnego, t. 7, wyd. 2, Warszawa 2004, s. 179; zob. też J. Szczotka, op.cit., s. 62 oraz J. Jezioro, op.cit., s. 179.

12 Por. J. Jezioro, op.cit., s. 178 oraz E. Habryn-Motawska, op.cit., s. 79.

${ }^{13} \mathrm{~W}$ odniesieniu do próbek towaru tak też wydaje się J. Szczotka, op.cit., s. 62 . 
próbki, opisy i wzory pochodzą nie od producenta, ale od sprzedawcy. W tym ostatnim przypadku publicznie dostępnych próbek/ /wzorów/opisów towaru, mimo iż zostały one przedstawione konsumentowi przez sprzedawcę, nie będzie też można - jak się wydaje traktować jako jednej z postaci tzw. indywidualnego uzgadniania właściwości towaru konsumpcyjnego, do którego odnosi się art. 4 ust. 2 ustawy o sprzedaży konsumenckiej ${ }^{14}$.

\subsection{Stosowanie przepisów o oświadczeniach woli}

O zapewnieniach publicznych $\mathrm{z}$ art. 4 ust. 3 zd. 2 ustawy o sprzedaży konsumenckiej jako o $\mathrm{z}$ reguły oświadczeniach wiedzy mówi Jerzy Szczotka ${ }^{15}$. Abstrahując od poprawności takiej kwalifikacji, co do której można by mieć pewne zastrzeżenia, zapewnień publicznych bez wątpienia nie powinno się utożsamiać $z$ oświadczeniami woli. Same zaś skutki prawne, jakie w razie zawarcia umowy sprzedaży tego rodzaju zapewnienia będą wywoływać, trzeba by uważać za biorące się nie $z$ treści czynności prawnej, lecz bezpośrednio $z$ (odpowiedniego) przepisu ustawy ${ }^{16}$. Mimo to - jak sugeruje Marlena Pecyna, a za nią pozostali przedstawiciele doktryny - przy dokonywaniu wykładni treści zapewnień publicznych będzie można posłużyć się regułami wyrażonymi w art. $65 \S 1$ k.c. ${ }^{17}$; a więc rozumieć takie zapewnienia tak, jak wymagają tego, ze względu na okoliczności, w jakich zostały one poczynione, zasady współżycia społecznego i ustalone zwyczaje. Jednocześnie za trafny należy uznać też pogląd Szczotki, odrzucający możliwość zastosowania

14 Szerzej zob. M. Koszowski, Indywidualne uzgadnianie właściwości towaru $w$ przypadku sprzedaży konsumenckiej, „Przegląd Ustawodawstwa Gospodarczego" 2013, nr 1, s. 8, 10.

${ }^{15}$ J. Szczotka, op.cit., s. 61.

${ }^{16}$ Zgodnie $z$ art. 56 k.c.: „Czynność prawna wywołuje nie tylko skutki w niej wyrażone, lecz również te, które wynikają z ustawy, z zasad współżycia społecznego i z ustalonych zwyczajów".

17 M. Pecyna, op.cit., s. 138; J. Szczotka, op.cit., przypis 88 na s. 61; a $z$ zastrzeżeniem, że należy to czynić $z$ uwzględnieniem ochronnej funkcji (zasad wynikających z celów) ustawy o sprzedaży konsumenckiej: E. Habryn-Motawska, op.cit., s. 80 i J. Jezioro, op.cit., s. 179. 
w stosunku do zapewnień publicznych przepisów o wadach oświadczenia woli (art. 82-88 k.c.) ${ }^{18}$. W razie gdyby jednak na fakt złożenia zapewnienia publicznego powołała się osoba, która doprowadziła do złożenia tego zapewnienia w sposób sprzeczny z zasadami współżycia społecznego, fakt ten należałoby uważać za względem tej osoby prawnie nieskuteczny (tj. na podstawie przepisu $z$ art. 5 k.c. (nadużycie prawa) stosowanego wprost bądź per analogiam).

\section{Oczekiwania konsumentów}

By móc domniemywać zgodności towaru konsumpcyjnego $\mathrm{z}$ umową, w myśl art. 4 ust. 3 zd. 2 ustawy o sprzedaży konsumenckiej towar wydany kupującemu musi odpowiadać oczekiwaniom dotyczącym tego towaru, których podstawę stanowią zapewnienia publiczne pochodzące od pewnych kategorii podmiotów ${ }^{19}$. Ustawa ta nie precyzuje już jednak tego, jakie to mają być oczekiwania: czy wszystkie, czy tylko niektóre $z$ nich, wyselekcjonowane za pomocą jakiegoś niewymienionego w niej z nazwy kryterium. W celu usunięcia tej nieścisłości jako zasadne jawi się zastosowanie do nakazu prounijnej wykładni prawa krajowego, a więc zinterpretowanie przepisu $\mathrm{z}$ art. 4 ust. 3 zd. 2 ustawy o sprzedaży konsumenckiej w zgodzie $z$ art. 2 ust. 2 lit. d dyrektywy, która jasno postanawia, że relewantne są tylko racjonalne [rozsądne - M. K.] oczekiwania

18 J. Szczotka, op.cit., s. 61-62.

${ }^{19}$ Mimo iż w art. 4 ust. 3 zd. 2 ustawy o sprzedaży konsumenckiej mowa jest o „oczekiwaniach dotyczących towaru tego [w domyśle: samego co towar wydany kupującemu - M. K.] rodzaju” nie wydaje się uzasadnione stanowisko, iż w świetle domniemania $z$ tego przepisu relewantne są oczekiwania dotyczące wszystkich towarów, jakie przynależą do towarów danego rodzaju. Punktem odniesienia dla wspomnianych oczekiwań jest bowiem towar nabyty przez kupującego, ewentualnie towary względem tego towaru identyczne, w sensie: stanowiące poszczególne egzemplarze (sztuki) „tego samego” towaru. Znamienne jest również, iż treść art. 4 ust. 3 zd. 2 ustawy o sprzedaży konsumenckiej nie pokrywa się tu $z$ brzmieniem art. 2 ust. 2 lit. d dyrektywy; jeśliby zatem interpretować 4 ust. 3 zd. 2 ustawy o sprzedaży konsumenckiej inaczej aniżeli zostało to uczynione powyżej, należałoby rozważyć, czy nie doszło przypadkiem do nieprawidłowej implementacji dyrektywy do polskiego prawa krajowego. 
konsumenta, jak i - jak się wydaje - wskazuje, że przy określaniu tych oczekiwań, oprócz zawartości samych publicznych zapewnień (oświadczeń), należy uwzględniać również charakter towarów, jakich dane oczekiwania dotyczą ${ }^{20}$.

Takie kryterium rozsądności („racjonalności”) oczekiwań, obwarowane dodatkowo charakterem poszczególnych towarów, po pierwsze, eliminowałoby te wszystkie $z$ publicznych zapewnień, które traktowałyby o właściwościach (zdatność do celów), jakich towary danego rodzaju $z$ definicji posiadać nie mogą: np. ukazanie w reklamie dotyczącej napoju energetycznego człowieka, któremu po wypiciu tego typu napoju wyrastają skrzydła, i który dzięki takim skrzydłom zaczyna latać.

Po drugie, jak się wydaje, kryterium to należy rozumieć w ten sposób, że konsument winien, kierując się rozsądkiem, oceniać zawartość publicznych zapewnień. Wniosek taki znajduje też pewne wsparcie $\mathrm{w}$ przepisie $\mathrm{z}$ art. 7 ustawy o sprzedaży konsumenckiej (art. 2 ust. 3 dyrektywy), jaki zwalnia sprzedawcę $z$ odpowiedzialności za zgodność towaru konsumpcyjnego $z$ umową wówczas, gdy kupujący w chwili zawarcia umowy o danej niezgodności wiedział lub - oceniając rozsądnie - powinien był wiedzieć. Jeśli bowiem konsument był (oceniając rozsądnie, powinien być) świadomy tego, że jakieś zapewnienie publiczne nie może być prawdziwe, należałoby uznać, że tym samym wiedział on (oceniając rozsądnie, powinien był wiedzieć) o niezgodności z umową, polegającej na nieodpowiadaniu przez towar temu zapewnieniu. Jednakowoż, niejako równocześnie,

20 „Domniemywa się, że towary konsumpcyjne są zgodne $z$ umową, jeżeli [...] wykazują jakość i wykonanie, które są normalne dla towarów tego samego rodzaju i jakich konsument może racjonalnie oczekiwać, biorąc pod uwagę charakter towarów i wszelkie oświadczenia publiczne na temat szczególnych właściwości towarów, jakie wygłosił na ich temat sprzedawca, producent lub ich przedstawiciel, w szczególności w reklamie lub na etykiecie”. O tym, że „ocena zgodności towaru z umową następuje na podstawie powszechnych, rozsądnych oczekiwań, w tym również oczekiwań opartych na reklamie”, znajduje się też wzmianka w rządowym uzasadnieniu do projektu ustawy o sprzedaży konsumenckiej. Zob. projektu ustawy o szczególnych warunkach sprzedaży konsumenckiej oraz zmianie Kodeksu cywilnego wraz z rządowym uzasadnieniem, druk sejmowy nr 465, http://orka.sejm.gov.pl/Druki4ka.nsf/ wgdruku/465/\$file/465.pdf, s. 20 (dostęp: 20.03.2002). 
trzeba mieć tu na uwadze również i to, że treści podawane do wiadomości publicznej nie mogą, tym bardziej jeszcze $z$ rozmysłem, wprowadzać konsumentów w błąd. W rezultacie, ilekroć $\mathrm{z}$ okoliczności towarzyszących składanemu publicznie zapewnieniu wynika, że informacje w nim zawarte mają być przez odbiorców traktowane jako niepodlegające subiektywnej ocenie - w szczególności odnosząc się do opisu technicznego towaru, jego składu surowcowego, technologii wykorzystanych do jego wytworzenia lub innych pozwalających się obiektywnie stwierdzić i zarazem możliwych do wystąpienia $z$ uwagi na charakter danego towaru właściwości lub zdatności do określonych celów - to wówczas, co do zasady, sprzedawca nie będzie się mógł powoływać na obowiązek wykazania się przez konsumenta rozsądkiem. Teza ta podyktowana jest także tym, że to właśnie zawartość takich informacji, w przypadku osoby działającej racjonalnie, ma bezpośredni wpływ na wybór konkretnego towaru spośród wszystkich oferowanych w sprzedaży towarów danego rodzaju.

Ponadto należy uznać, że mimo ogólnego wymogu kierowania się rozsądkiem, konsument nie jest w żaden sposób zobligowany do podejmowania jakichkolwiek, nawet zupełnie nieskomplikowanych, działań, jakie miałyby na celu zweryfikowanie prawdziwości i rzetelności treści będących przedmiotem publicznych zapewnieńn ${ }^{21}$. W przypadku tego wymogu chodzi bowiem jedynie o ocenę zawartości publicznego zapewnienia, jaka odbywa się w umyśle ludzkim na podstawie już zgromadzonych (w pamięci krótko- lub długoterminowej) danych i informacji, a więc o proces „czysto” psychiczny, a nie o przedsiębranie w świecie „zewnętrznym” czynności zmierzających do pozyskiwania nowej wiedzy i doświadczeń.

Istotnym problemem, jaki wiąże się $\mathrm{z}$ obowiązkiem poddawania zawartości publicznych zapewnień rozsądnej ocenie, stanowi kwestia tego, czy wspomniana ocena ma być dokonywana przez pryzmat „rozsądku” konkretnej osoby (tej, która rzeczywiście nabyła dany towar), czy też przez pryzmat „rozsądku” jakiegoś abstrakcyjnego wzorcowego/modelowego konsumenta. Między innymi ze względów dowodowych oraz konieczności obiektywizacji odpowiedzialności

${ }^{21}$ Podobnie E. Habryn-Motawska, op.cit., s. 74, 96. 
sprzedawcy, zasadne wydaje się opowiedzenie za tym drugim rozwiązaniem wraz z uściśleniem, że przez konsumenta, który ma służyć za wzór/model, będziemy rozumieć przeciętnego potencjalnego odbiorcę danego zapewnienia tudzież zapewnień danego rodzaju ${ }^{22}$.

Przy tym, w przypadku, gdy kto inny jest kupującym, a kto inny adresatem publicznych zapewnień (np. zabawka dla dzieci nabywana przez osobę dorosłą), relewantny wydaje się rozsądek tego drugiego (jego wzorcowej/modelowej postaci) - tj. dotyczy to przynajmniej w tych wszystkich sytuacjach, w jakich reguła odwrotna działałaby na niekorzyść konsumenta. Aczkolwiek trzeba mieć tu ciągle na uwadze, że osobą (w tym abstrakcyjną), której rozsądek ma stanowić wyznacznik dla dokonywania rozsądnej oceny treści publicznych zapewnień, będzie mogła być tylko taka osoba, która jeśli sama zawarłaby - występując po stronie kupującego - umowę sprzedaży towaru, jakiego dotyczy dane zapewnienie publiczne, to podpadałaby pod zakres podmiotowy stosowania ustawy o sprzedaży konsumenckiej (mogąc na zasadach określonych w tej ustawie skorzystać z uprawnień przewidzianych na wypadek niezgodności towaru konsumpcyjnego $z$ umową) $)^{23}$.

\section{Oznakowanie towaru}

Za szczególnie istotne postacie publicznych zapewnień ustawa o sprzedaży konsumenckiej uznaje zapewnienia wyrażone w oznakowaniu towaru oraz w reklamie (art. 4 ust. 3 zd. 2 in fine). Podobnie, w art. 2 ust. 2 lit. d, czyni też implementowana tą ustawą dyrektywa.

22 Podobnie M. Pecyna, op.cit., s. 136-137 oraz E. Habryn-Motawska, op.cit., s. 73; zob. też J. Jezioro, op.cit., s. 177. Szerzej na temat wzorca (modelu) konsumenta, jaki jest właściwy dla stosunków sprzedaży konsumenckiej, zob. M. Koszowski, Wiedza o niezgodności towaru konsumpcyjnego z umowa, „Studia Prawa Prywatnego” 2012, nr 3-4, s. 69.

23 Tak też M. Pecyna, op.cit., s. 138 oraz E. Habryn-Motawska, op.cit., s. 77. Zgodnie $z$ art. 1 ust. 1 ustawy o sprzedaży konsumenckiej ustawę tę stosuje się do dokonywanej w zakresie działalności przedsiębiorstwa sprzedaży rzeczy ruchomej osobie fizycznej, która nabywa tę rzecz w celu niezwiązanym z działalnością zawodową lub gospodarczą. 
Potencjalnie na towarze (jego opakowaniu, etykiecie) mogą się znaleźć jakieś wyrażenia będące ogólnymi zwrotami czy też znakami graficznymi, których celem jest przekonanie - niekoniecznie myślącego racjonalnie - konsumenta do dokonania zakupu. W przeważającej jednak mierze na towarach (ich opakowaniach, etykietach) zamieszcza się informacje bardziej szczegółowe („konkretne”), dotyczące bądź składu surowcowego, technologii wytwarzania, przeznaczenia, sposobu użycia, bądź też innych jeszcze parametrów fizyko-chemicznych i użytkowych danego towaru, jak np. jego energochłonność, bezpieczeństwo, wytrzymałość (trwałość) itp. Tego też rodzaju informacje, jako że co do zasady są w wysokim stopniu dookreślone i pozbawione ocennej treści, powinny bezwzględnie wiązać sprzedawcę, tj. bez konieczności poddawania ich krytycznej ocenie ze strony konsumentów.

Samo to, czym jest oznakowanie towaru, można by tutaj - jak wskazuje się w doktrynie - próbować pojmować na dwa sposoby, tj.: węziej, jako fizyczne opatrzenie towaru (jego opakowania, etykiety) jakimś słowem/zwrotem/cyfrą lub znakiem graficznym, oraz szerzej, jako pewien kontekst wyznaczany również przez inne okoliczności, w tym zwłaszcza fakt umieszczenia oferowanego towaru w takim, a nie innym miejscu (tzw. oznakowanie dorozumiane) ${ }^{24}$. To drugie $z$ sugerowanych znaczeń, użytego w ustawie o sprzedaży konsumenckiej, zwrotu: „oznakowanie towaru”, głównie ze względów językowych, wydaje się być jednak nieco wątpliwe; co nie oznacza jednakże, że ustawienie oferowanego w sprzedaży towaru pośród produktów, jakie kojarzą się z wyższą aniżeli zazwyczaj jakością, nie powinno zostać uznane za jedną - niż oznakowanie towaru $\mathrm{z}$ możliwych postaci zapewnienia publicznego $\mathrm{w}$ rozumieniu art. 4 ust. 3 zd. 2 ustawy o sprzedaży konsumenckiej ${ }^{25}$.

Z pewnością pod oznakowanie towaru będą natomiast podpadać znaki jakości i oznaczenia pochodzenia geograficznego, jakie umieszczono na towarze, jego opakowaniu i etykiecie. Pierwsze

${ }^{24}$ Zob. E. Habryn-Motawska, op.cit., s. 81 oraz J. Jezioro, op.cit., s. 179-180.

${ }^{25}$ Tak też E. Habryn-Motawska, op.cit., s. 81-82. Za szerokim rozumieniem na potrzeby ustawy o sprzedaży konsumenckiej terminu „oznakowanie towaru” wydaje się być natomiast M. Pecyna, op.cit., s. 138. 
z nich będą rodzić oczekiwania u konsumentów odnośnie do tego, że oferowany im towar spełnił wymagania (odznacza się biorącymi się z tego faktu właściwościami/zdatnością do określonych celów), jakim zadośćuczynienie było konieczne w świetle zasad nadawania tudzież posługiwania się danym znakiem jakości. Drugie z kolei, oznaczenia pochodzenia geograficznego, będą uzasadniać oczekiwania w zakresie tego, że towar wystawiony na sprzedaż pochodzi $z$ regionu (miejscowości), $z$ jakim w przypadku towarów tego samego co on rodzaju można wiązać określone właściwości/zdatność do określonych celów; a tym samym i uzasadniać oczekiwania w zakresie tego, że takimi właściwościami (zdatnością do celów) towar ten się rzeczywiście cechuje ${ }^{26}$.

\section{Reklama}

Obecność, ale też i nachalność, reklamy zdaje się dzisiaj nierozłącznie związana $z$ obrotem konsumenckim. Bezpośrednie odniesienie się do niej w art. 4 ust 3 zd. 2 ustawy o sprzedaży konsumenckiej oraz art. 2 ust. 2 lit. d dyrektywy można by przy tym uznawać za przejaw ogólnego trendu przyjmowania rozwiązań prawnych mających za zadanie przeciwdziałać nierzetelnym treściom reklamowym ${ }^{27}$. Temu celowi niewątpliwie służy również art. 16 Ustawy z dnia 16 kwietnia 1993 r. o zwalczaniu nieuczciwej konkurencji (Dz.U. z 1993 r. Nr 47, poz. 211 wraz z późniejszymi zmianami), który dookreśla, kiedy w szczególności reklamę powinno trak-

${ }^{26} \mathrm{Na}$ temat zapewnień publicznych mających postać znaku jakości i oznaczenia pochodzenia geograficzne zob. M. Pecyna, op.cit., s. 138-139; E. Habryn-Motawska, op.cit., s. 82, 85-86, 87-89; J. Jezioro, op.cit., s. 180. O tym, że towar ma się odznaczać pewnymi właściwościami/zdatnością do określonych celów, może też świadczyć znak towarowy, jaki kojarzy się z wyrobami o ponadprzeciętnej jakości, i to nawet wówczas, gdy dotychczas opatrywane tym znakiem były towary zupełnie innego rodzaju. Zob. E. Habryn-Motawska, op.cit., s. 82, 83-85 oraz M. Pecyna, op.cit., s. 139. Odnośnie do towarów konsumpcyjnych z oznaczeniem CE zob. E. Habryn-Motawska, op.cit., s. 86-87.

${ }_{27}$ Zob. projekt ustawy o szczególnych warunkach sprzedaży konsumenckiej oraz zmianie Kodeksu cywilnego wraz z rządowym uzasadnieniem, s. 20, 29; zob. też M. Pecyna, op.cit., s. 139. 
tować się jako czyn nieuczciwej konkurencji. W przeciwieństwie jednak do ustawy o zwalczaniu nieuczciwej konkurencji, ustawa o sprzedaży konsumenckiej i dyrektywa nie normują kwestii ogólnej odpowiedzialności danego podmiotu za reklamę, jaka jest sprzeczna z prawem lub dobrymi obyczajami. Te akty prawne regulują jedynie (a w zasadzie przybliżają) wpływy treści reklamowych na (nie)zgodność towaru konsumpcyjnego $z$ umową; przy czym obarczenie sprzedawcy, w ramach tej instytucji, niekorzystnymi skutkami prawnymi w przypadku nieuczciwej reklamy ma być uzasadnione głównie tym, że czerpie on wymierne korzyści z działalności reklamowej, uzyskując dzięki niej większe obroty (zyski) ${ }^{28}$.

\subsection{Definicja}

Ustawa o sprzedaży konsumenckiej, podobnie jak i implementowana za pośrednictwem tej ustawy dyrektywa, w żaden sposób nie wyjaśnia tego, co należy rozumieć pod pojęciem reklamy. Definicję terminu „reklama” zawiera natomiast dyrektywa Rady nr 84/450/ /EWG z dnia 10 września 1984 r. w sprawie zbliżenia przepisów ustawowych, wykonawczych i administracyjnych Państw Członkowskich dotyczących reklamy wprowadzającej w błąd (Dz.U. L 250, z dnia 19 września 1984 r.). Zgodnie $z$ art. 2 pkt 1 tej dyrektywy reklamę stanowi: „przedstawienie w jakiejkolwiek formie w ramach działalności handlowej, gospodarczej, rzemieślniczej lub wykonywania wolnych zawodów w celu wspierania zbytu towarów lub usług, w tym nieruchomości, praw i zobowiązań".

Posiłkując się tą legalną definicją oraz mając na uwadze charakterystykę publicznego zapewnienia przedstawioną w pkt 2.1 i 2.2 niniejszego artykułu, przez reklamę, mieszczącą w sobie zapewnienie publiczne, należałoby uważać każde publiczne działanie (wypowiedź, wystąpienie, przedstawienie), jakie ma na celu zachęcić (nakłonić) konsumenta do nabycia danego towaru, oraz polega na przekazie informacji na temat tego towaru; a zwłaszcza takie tego

${ }^{28}$ Zob. projekt ustawy o szczególnych warunkach sprzedaży konsumenckiej oraz zmianie Kodeksu cywilnego wraz z rządowym uzasadnieniem, s. 20; zob. też M. Pecyna, op.cit., s. 141 oraz S. Grundmann, w: EU Sales, s. 139. 
typu działanie, które zmierza do zaprezentowania danego towaru jako pod jakimś względem(ami) lepszego od innych towarów należących do tego samego rodzaju ${ }^{29}$. Ponadto, jak się wydaje, reklama mająca stanowić zapewnienie publiczne w rozumieniu art. 4 ust. 3 zd. 2 ustawy o sprzedaży konsumenckiej (art. 2 ust. 2 lit. d dyrektywy) powinna być źródłem informacji na temat właściwości (zdatności do szczególnych celów), których posiadanie przez towar pozwala się w jakiś obiektywny, choćby w praktyce nawet bardzo trudny, sposób zweryfikować ${ }^{30}$.

Pewne wątpliwości mogą wiązać się $z$ tzw. reklamą niepełną, $\mathrm{tj}$. taką reklamą, jaka pomijając informacje istotne $z$ punktu widzenia jej adresata, wprowadza go w błąd ${ }^{31}$. Ani bowiem ustawa, ani dyrektywa nie rozstrzyga wprost tego, czy, by móc domniemywać zgodność danego towaru konsumpcyjnego $\mathrm{z}$ umową, towar ten musi odpowiadać oczekiwaniom, jakie powstały u konsumentów na skutek reklamy niepełnej. Zasadna wydaje się tu jednak odpowiedź twierdząca ${ }^{32}$; choćby $z$ tego powodu, iż sprzedawca może odnosić korzyści w postaci zwiększonych obrotów (zysków), również i z tego typu reklamy.

\subsection{Rozsądna ocena}

W stosunku do zapewnień publicznych wyrażonych w reklamie bardziej doniosły, aniżeli ma to miejsce w przypadku innych postaci publicznych zapewnień, wydaje się wymóg poddawania treści takich zapewnień rozsądnej ocenie. W konsekwencji Pecyna uważa, że roz-

${ }^{29}$ Odnośnie do pojęcia reklamy na tle ustawy o sprzedaży konsumenckiej por. też E. Habryn-Motawska, op.cit., s. 89-90; J. Jezioro, op.cit., s. 180-181 oraz M. Pecyna, op.cit., s. 139-141. Co do pojęcia towaru danego rodzaju zob. M. Koszowski, Zwykły użytek, s. 24-25.

30 Wyrażenia „najszybszy”, „najtańszy”, „w całej gamie kolorów” jako przykłady wiążących [dających się zweryfikować - M. K.] sformułowań reklamowych podaje K. Grzybczyk, Ochrona konsumenta przed nieuczciwa reklama, w: Europejskie prawo konsumenckie a prawo polskie, red. E. Nowińska i P. Cybula, Kraków 2005, s. 227-228.

${ }^{31} \mathrm{~W}$ przedmiocie reklamy niepełnej zob. ibidem, s. 226.

32 Tak też wydaje się E. Habryn-Motawska, op.cit., s. 94. 
sądek oczekiwań będzie pełnił „role filtra wykluczającego z zakresu ochrony bezkrytyczną, naiwną wiarę w prawdziwość całej treści reklamowej”33. Inni z kolei twierdzą, że podstawą uznania towaru za niezgodny $z$ umową nie może być reklama zawierająca zapewnienia, które oceniając rozsądnie, nie mogą być prawdziwe ${ }^{34}$ tudzież zwracają uwagę na potrzebę rozdzielania w przypadku reklamy sfery informacyjnej (jaka może mieć znaczenie dla określenia (nie)zgodności towaru konsumpcyjnego $z$ umową) od sfery perswazji (jaka pozostawać ma dla kwestii (nie)zgodności towaru konsumpcyjnego Z umową irrelewantna) ${ }^{35}$. W piśmiennictwie ogólnie nadmienia się też, że do istoty każdej reklamy należy pewna przesada ${ }^{36}$.

Ponadto, przy ustalaniu tego, jakie $z$ oczekiwań konsumentów opartych na publicznych zapewnieniach wyrażonych w reklamie stanowią oczekiwania rozsądne, dużą wagę - jak się wydaje większą niż w stosunku do innych rodzajów zapewnień publicznych winno się przywiązywać do kategorii potencjalnych odbiorców. Stąd np. reklama skierowana do adresatów łatwowiernych i szczególnie wrażliwych, takich jak np. dzieci, będzie musiała spełniać wyższe wymagania co do jej „prawdziwości”/rzetelności ${ }^{37}$, a tym samym być traktowana $z$ punktu widzenia obowiązku rozsądnej oceny mniej rygorystycznie. W efekcie, by móc się skutecznie powołać na domniemanie zgodności towaru konsumpcyjnego $z$ umową, sprzedawca będzie musiał wykazać, że każde przeciętne rozsądne dziecko w określonej grupie wiekowej uznałoby daną treść reklamową za nieprawdziwą; nie wystarczy natomiast to, że udowodni

${ }^{33}$ M. Pecyna, op.cit., s. 141.

${ }^{34}$ W. Czachórski, A. Brzozowski, M. Safian, E. Skowrońska-Bocian, Zobowiązania. Zarys wykładu, wyd. 11, Warszawa 2009, s. 412. Zob. też I. Wesołowska, Zapewnienia reklamowe, Nowa ustawa o sprzedaży konsumenckiej, część 2: Obowiązki sprzedawcy, „Vademecum Rzeczpospolitej” 5 marca 2003, nr 47 [54 (6434)], s. 10.

${ }^{35}$ E. Habryn-Motawska, op.cit., s. 94-95. O braku odpowiedzialności sprzedawcy za treść reklamy, jaka odnosi się do społecznych funkcji towaru tudzież wpływa na sferę emocji lub wyobraźni, mówiąc np. o skutkach nabycia określonego towaru, wspomina również M. Pecyna, op.cit., s. 141.

${ }^{36}$ K. Grzybczyk, op.cit., s. 227. Zob. też E. Łętowska, Europejskie prawo umów konsumenckich, Warszawa 2004, s. 288, I. Wesołowska, op.cit., s. 10.

${ }^{37}$ Por. K. Grzybczyk, op.cit., s. 228-229. 
on, iż żaden $z$ dorosłych, oceniających tę treść rozsądnie, nie dałby wiary zawartym w niej zapewnieniom. Przy tym - zgodnie $z$ uwagami poczynionymi w pkt 3 niniejszego artykułu - sam fakt, że to osoba dorosła, a nie dziecko, nabywa towar konsumpcyjny przeznaczony dla dzieci, będzie pozostawać tu bez znaczenia, tj. przynajmniej tak długo, jak długo uwzględnienie tego faktu miałoby być ze skutkiem na niekorzyść kupującego.

\subsection{Stosunek art. 4 ust. 3 zd. 2 ustawy o sprzedaży konsumenckiej do art. 71 k.c.}

W kontekście reklamy mającej wpływać na (nie)zgodność towaru konsumpcyjnego $z$ umową, odrębnego omówienia wymaga relacja, w jakiej pozostaje art. 4 ust. 3 zd. 2 ustawy o sprzedaży konsumenckiej do art. 71 k.c. Otóż, we wspomnianym artykule Kodeksu cywilnego ustanowiono m.in. regułę interpretacyjną, według której w razie wątpliwości reklamy nie powinno się uważać za ofertę, lecz jedynie za zaproszenie do zawarcia umowy ${ }^{38}$. Reguła ta dotyczy tym samym jednego $z$ możliwych sposobów zawarcia umowy: drogą złożenia oferty i jej przyjęcia; zakazując poczytywania treści reklamowych za ofertę, ilekroć zachodzą w tym względzie jakieś wątpliwości. Artykuł 4 ust. 3 zd. 2 ustawy o sprzedaży konsumenckiej odnosi się z kolei do domniemania zgodności towaru konsumpcyjnego $z$ umową, które to domniemanie nie pozostaje w żadnym związku z samym sposobem, za pomocą którego doszło do zawarcia umowy (tutaj sprzedaży). W konsekwencji hipotezy norm $z$ art. 4 ust. 3 zd. 2 ustawy o sprzedaży konsumenckiej oraz $\mathrm{z}$ art. 71 k.c. nie pokrywają się, a ich dyspozycje wzajemnie nie wykluczają; w wyniku tego nie ma między tymi normami jakiejkolwiek sprzeczności.

38 „Ogłoszenia, reklamy, cenniki i inne informacje, skierowane do ogółu lub do poszczególnych osób, poczytuje się w razie wątpliwości nie za ofertę, lecz za zaproszenie do zawarcia umowy". 
Unormowanie $z$ art. 71 k.c. można by jednak, przynajmniej prima facie, rozumieć również inaczej, tj. że treści reklamowe w razie powstania co do tego wątpliwości nie tylko nie mogą być traktowane jako element oferty, ale i być wiążące dla sprzedawcy niezależnie od tego, co miałoby być podstawą takiego związania. Nie wchodząc w bardziej szczegółowe rozważania co do poprawności takiego sposobu wykładni przepisu $\mathrm{z}$ art. 71 k.c., w przypadku jego obrania przepis ten w zakresie, w jakim nie daje się on pogodzić $z$ unormowaniem $z$ art. 4 ust. 3 zd. 2 ustawy o sprzedaży konsumenckiej, należałoby uważać za lex generalis.

$\mathrm{W}$ obu jednak tych przypadkach zamieszczone w rządowym uzasadnieniu do projektu ustawy o sprzedaży konsumenckiej stanowisko, iż stosowanie reguły interpretacyjnej $z$ art. 71 k.c. $z$ racji, iż według tego projektu reklama staje się elementem oferty, będzie w stosunkach sprzedaży konsumenckiej bezprzedmiotowe, jawi się jako zbyt daleko idące ${ }^{39}$. Nawet bowiem w razie potraktowania tu art. 4 ust. 3 zd. 2 ustawy o sprzedaży konsumenckiej jako lex specialis wciąż nie powinno być wolno poczytywać treści reklamowej za złożenie prawnie wiążącej oferty zawarcia umowy sprzedaży, jeśli zachodzą ku temu wątpliwości.

\section{Termin trwałości}

Z przedmiotu zapewnień publicznych odnoszących się do właściwości towaru konsumpcyjnego, jakie mogą być wyrażone na opakowaniu towaru lub w jego reklamie, ustawa o sprzedaży konsumenckiej explicite nie wyłącza określenia terminu, w jakim właściwości te mają być zachowane (art. 4 ust. 3 zd. 2 in fine). Choć w art. 2 ust. 2 lit. d dyrektywy brak jest jakiejkolwiek wzmianki na temat tego typu terminu, to nie powinno jednak ulegać wątpliwości, że podanie w sposób dostępny dla publiczności terminu trwałości (przydatności do spożycia), o ile tylko będzie on dłuższy od okresu trwałości (zdatności do spożycia), jaki jest typowy dla towarów

39 Projekt ustawy o szczególnych warunkach sprzedaży konsumenckiej oraz zmianie Kodeksu cywilnego wraz z rządowym uzasadnieniem, s. 11. 
danego rodzaju, stanowi - zarówno na gruncie ustawy, jak i dyrektywy - jedną z możliwych postaci publicznego zapewnienia, o jakim jest mowa w tych aktach prawnych. Pewnym problemem pozostaje wskazanie w zapewnieniu publicznym terminu krótszego od okresu trwałości (daty przydatności do spożycia), jaki jest typowy dla towarów danego rodzaju. Jak się bowiem wydaje, w takim przypadku będzie mogło dojść do zwolnienia sprzedawcy z odpowiedzialności, ilekroć zostanie spełniona hipoteza normy $z$ art. 7 ustawy o sprzedaży konsumenckiej (art. 2 ust. 3 dyrektywy) ${ }^{40}$.

\section{Podmioty mogące składać publiczne zapewnienia}

Zgodnie $z$ art. 4 ust. 3 zd. 2 oraz art. 4 ust. 4 ustawy o sprzedaży konsumenckiej dla oczekiwań, jakim ma odpowiadać towar konsumpcyjny, by można było domniemywać jego zgodność z umową, znaczenie mają tylko te $z$ publicznych zapewnien, które składane są przez: a) sprzedawcę, producenta, jego przedstawiciela, b) osobę, jej przedstawiciela, która przez umieszczenie na towarze swojej nazwy, znaku towarowego lub innego oznaczenia odróżniającego podaje się za producenta, oraz c) osobę, jej przedstawiciela, która wprowadza towar konsumpcyjny do obrotu krajowego w zakresie działalności swojego przedsiębiorstwa. Również w świetle regulacji z dyrektywy (jej art. 1 ust. 2 lit. c i d oraz art. 2 ust. 2 lit. d) prawnie relewantne mają być tylko zapewnienia pochodzące od niektórych podmiotów. Co do zasady ich kategorie odpowiadają rodzajom podmiotów wymienionych w ustawie o sprzedaży konsumenckiej, aczkolwiek, o czym w szczegółach będzie mowa poniżej, występują tu też pewne subtelne różnice.

${ }^{40}$ Odnośnie do zagadnienia terminu trwałości (daty przydatności do spożycia) w odniesieniu do towarów konsumpcyjnych, w tym kwestii barku odpowiedzialności sprzedawcy za utratę przez towar właściwości po upływie takiego terminu, zob. M. Koszowski, Wiedza o niezgodności, s. 71 oraz idem, Zwykły użytek, s. 27. 


\subsection{Sprzedawca}

Pod pojęciem sprzedawcy, w kontekście podmiotów mogących składać prawnie relewantne zapewnienia publiczne, należy rozumieć osobę (fizyczną, prawną lub nieposiadającą osobowości prawnej, ale mającą zdolność prawną [art. $33^{1} \S 1$ k.c.]), która w zakresie działalności swojego przedsiębiorstwa (wykonywania działalności gospodarczej lub zawodowej) dokonuje (zawiera umowy) sprzedaży towarów konsumpcyjnych - art. 1 ust. 1 ustawy $^{41}$ oraz art. 1 ust. 2 lit. c dyrektywy ${ }^{42}$.

Przy tym za zapewnienia publiczne pochodzące od sprzedawcy (podobnie jak i innych podmiotów, o których stanowi art. 4 ust. 3 i 4 ustawy) powinno się uważać zapewnienia składane publicznie przez osoby, za których zachowania zgodnie $z$ polskim prawem cywilnym sprzedawca odpowiada jak za własne działania lub zaniechania, czyli osoby, o których mowa w art. 474 k.c. (tzw. pomocnicy i podwykonawcy) ${ }^{43}$.

\subsection{Producent}

Za producenta w rozumieniu art. 4 ust. 3 zd. 2 ustawy o sprzedaży konsumenckiej powinno się uznawać osobę, która w zakresie działalności swojego przedsiębiorstwa (wykonywania działalności gospodarczej lub zawodowej) wytwarza towar konsumpcyjny ${ }^{44}$. Wąt-

${ }^{41}$ „Ustawę stosuje się do dokonywanej w zakresie działalności przedsiębiorstwa sprzedaży rzeczy ruchomej osobie fizycznej, która nabywa tę rzecz w celu niezwiązanym $z$ działalnością zawodową lub gospodarczą (towar konsumpcyjny)”.

42 „Sprzedawca oznacza każdą osobę fizyczną lub prawną, która na podstawie umowy sprzedaje towary konsumpcyjne w ramach swojej działalności handlowej, przedsiębiorstwa lub zawodowej”. Odnośnie do definicji sprzedawcy na tle dyrektywy zob. też L. Serrano, w: EU Sales Directive, s. 114.

${ }^{43}$ Podobnie M. Pecyna, op.cit., s. 142. Zob. też pkt 7.5 niniejszego artykułu.

${ }^{44}$ Odmiennie, bo niezależnie od tego, czy do wytworzenia towaru doszło w ramach prowadzonej przez dany podmiot działalności gospodarczej, osobę producenta (o której stanowi art. 4 ust. 3 zd. 2 ustawy o sprzedaży konsumenckiej) rozumie J. Jezioro, op.cit., s. 182. Zob. też M. Pecyna, op.cit., s. 142-143. 
pliwości może budzić tu sytuacja, w której dany podmiot wytwarza towary w ramach swojego przedsiębiorstwa, lecz w cudzym imieniu i na cudzy rachunek. Jak się bowiem wydaje, to wciąż on będzie pozostawał producentem towaru, a osobę, na której rzecz i w której imieniu towary zostały wytworzone, o ile to ona przez zamieszczenie na towarze oznaczenia odróżniającego podaje się za producenta, będzie należało traktować jako tzw. quasi-producenta (zob. pkt 7.4 niniejszego artykułu).

\subsection{Importer i dystrybutor}

Artykuł 4 ust. 4 ustawy o sprzedaży konsumenckiej zrównuje z zapewnieniami publicznymi pochodzącymi od producenta zapewnienia składane publicznie przez osobę, która w zakresie działalności swojego przedsiębiorstwa wprowadza towar konsumpcyjny do obrotu krajowego. Dyrektywa w tym miejscu wspomina jedynie o importerze towarów konsumpcyjnych na terytorium Wspólnoty (dzisiejszej Unii Europejskiej) - art. 1 ust. 2 lit. d dyrektywy.

Jak się wydaje, polski ustawodawca, korzystając $z$ klauzuli minimalnej harmonizacji (jaką zawiera art. 8 ust. 2 dyrektywy), rozszerzył katalog podmiotów, których zapewnienia publiczne mogą mieć wpływ na prawnie relewantne oczekiwania konsumentów, na osoby, które nie będąc importerami na terytorium Unii Europejskiej (nie sprowadzając towarów spoza UE) ani nawet importerami na terytorium Polski, wprowadzają towary konsumpcyjne do obrotu krajowego w zakresie działalności swojego przedsiębiorstwa (wykonywanej działalności gospodarczej lub zawodowej) ${ }^{45}$. Pecyna wskazuje tu również na różnicę $\mathrm{w}$ brzmieniu przepisu $\mathrm{z}$ art. 4 ust. 4 ustawy o sprzedaży konsumenckiej oraz z art. $449 \S 2$ zd. 2 k.c.

${ }^{45}$ Podobnie wydaje się E. Wieczorek, która twierdzi, że krąg podmiotów [za których zapewnienia publiczne odpowiada sprzedawca - M. K.] został ujęty [w ustawie o sprzedaży konsumenckiej - M. K.] szerzej niż w dyrektywie; E. Wieczorek, op.cit., s. 50. Na temat klauzuli minimalnej harmonizacji zawartej w art. 8 ust. 2 dyrektywy zob. M. Koszowski, Zasady interpretacji aktów prawnych powstałych w wyniku implementacji dyrektywy 99/44/WE na przykładzie polskiej ustawy o sprzedaży konsumenckiej, „Przegląd Legislacyjny” 2010, nr 3 (73), s. 26-35 oraz S. Grundmann, w: EU Sales, s. 270-275. 
Ten drugi zawiera bowiem definicję legalną importera, w myśl której importerem jest ten, kto w zakresie swojej działalności gospodarczej wprowadza do obrotu krajowego produkt, ale pochodzenia zagranicznego ${ }^{46}$. Podążając też tym tokiem rozumowania, wspomniana autorka przez osobę wprowadzającą w zakresie swojego przedsiębiorstwa towar do obrotu krajowego (o której traktuje art. 4 ust. 4 ustawy o sprzedaży konsumenckiej) - w zależności od tego, czy jest to towar pochodzenia zagranicznego, czy krajowego - uznaje zarówno importera, jak i dystrybutora ${ }^{47}$.

Nieco bardziej problematyczne aniżeli samo wyszczególnienie obok osoby importera również osoby dystrybutora pozostaje to, czy pod pojęciem osoby wprowadzającej towar do obrotu krajowego w zakresie swojego przedsiębiorstwa, do której odnosi się art. 4 ust. 4 ustawy o sprzedaży konsumenckiej, należy rozumieć także podmiot, który wprowadza towar do obrotu krajowego innego niż Polska państwa członkowskiego Unii Europejskiej. Odpowiedź negatywna wydaje się naruszać zarówno zasadę wykładni prawa krajowego w zgodzie $z$ prawem unijnym, jak $\mathrm{i}-\mathrm{z}$ racji, iż mielibyśmy wówczas do czynienia $z$ pogorszeniem, a nie polepszeniem sytuacji prawnej konsumenta - wskazywać na fakt nieprawidłowej implementacji dyrektywy do polskiego porządku prawnego ${ }^{48}$. Doty-

${ }^{46}$ M. Pecyna, op.cit., s. 145-146 - w swoich rozważaniach autorka ta posłużyła się innym numerem artykułu Kodeksu cywilnego, tj. art. 449 § 2 , z przeprowadzonych przez nią wywodów w sposób jednoznaczny wynika jednak, że miała ona na myśli art. 449 § 2 zd. 2 k.c.

${ }^{47}$ Ibidem, s. 146; tak też J. Jezioro, op.cit., s. 184. Jeszcze dalej wydaje się tu iść J. Szczotka, który na tle art. 4 ust 4 ustawy o sprzedaży konsumenckiej mówi już nie tylko o importerze i dystrybutorze, ale także o przedsiębiorcy, jedynie montującym bądź składający produkt $z$ dostarczonych mu części, oraz hurtowniku, jeśli tylko wprowadzają oni towar konsumpcyjny do obrotu krajowego, a nawet o wszystkich podmiotach, jakie znajdują się w łańcuchu dystrybucyjnym pomiędzy producentem a konsumentem; J. Szczotka, op.cit., s. 64 .

${ }^{48}$ Zgodnie $\mathrm{z}$ klauzulą minimalnej harmonizacji, jaką zawiera art. 8 ust. 2 dyrektywy, państwa członkowskie mogą przyjąć lub utrzymać w mocy rozwiązania prawne różniące się od tych przewidzianych przez dyrektywę jedynie wtedy, gdy rozwiązania te będą surowszymi, w sensie zapewnienia konsumentom wyższego poziomu ochrony aniżeli poziom wynikający z regulacji zawartej w dyrektywie. 
czy to zwłaszcza tych przypadków, w jakich towar konsumpcyjny bezpośrednio przed wprowadzaniem do obrotu innego niż Polska państwa członkowskiego był sprowadzony z kraju, jaki nie przynależy do Unii Europejskiej ${ }^{49}$.

\subsection{Quasi-producent (producent nominalny)}

W art. 4 ust. 4 ustawy o sprzedaży konsumenckiej (art. 1 ust. 2 lit. d dyrektywy) mowa jest również o osobie, która nie będąc producentem, podaje się za niego przez umieszczenie na towarze swojej nazwy, znaku towarowego lub innego oznaczenia odróżniającego. Przy tym w literaturze przedmiotu osobę tę określać się zwykło mianem "quasi-producenta” bądź "producenta nominalnego"50. Mimo iż ustawa (dyrektywa) odnosi się tutaj wyłącznie do oznaczenia odróżniającego (znaku wyróżniającego) umieszczonego na towarze, zasadne wydaje się stanowisko, że takie oznaczenie może zostać zamieszczone nie tylko na samym towarze tudzież jego opakowaniu, etykiecie, ale również w treści instrukcji obsługi (montażu), karty gwarancyjnej i innych dokumentów wydanych kupującemu wraz z towarem (zwłaszcza gdy dokumenty takie znajdują się, wraz z towarem, w tym samym opakowaniu fabrycznym) ${ }^{51}$. Za quasi-producenta (producenta nominalnego) można by też uważać sprzedawcę, ilekroć ten, zamieszczając oznaczenie odróżniające, podaje się za producenta danego towaru; aczkolwiek taka kwalifikacja prawna nie wydaje się mieć większego, jeśli jakiegokolwiek, praktycznego znaczenia.

${ }^{49}$ Na węższe ujęcie importera w ustawie o sprzedaży konsumenckiej w zestawieniu $z$ jego ujęciem $w$ dyrektywie wskazuje J. Pisuliński, op.cit., przypis nr 588 na s. 178.

${ }^{50}$ Zob. M. Pecyna, op.cit., s. 146 i J. Jezioro, op.cit., s. 184.

${ }^{51}$ Odmiennie, tj. wykluczając możliwość umieszczenia oznaczenia w inny sposób aniżeli na samym towarze, np. tylko w dokumentacji sprzedaży i tego typu dokumentach, wydaje się ujmować tę kwestię J. Jezioro, op.cit., s. 184. Explicite, za oznaczenia odróżniające w rozumieniu art. 4 ust. 4 ustawy o sprzedaży konsumenckiej, nie uznaje oznaczeń znajdujących się na rachunku, fakturze, potwierdzeniu umowy bądź innym dokumencie handlowym, M. Pecyna, op.cit., s. $146-147$. 
Ponadto na równi $z$ quasi-producentem należałoby tu traktować quasi-importera i quasi-dystrybutora, a więc osobę, która, nie będąc importerem/dystrybutorem danego towaru, w opisany powyżej sposób się za niego podaje ${ }^{52}$.

\subsection{Przedstawiciel producenta, sprzedawcy, importera,} dystrybutora i quasi-producenta

Pod pojęciem przedstawiciela producenta - podobnie jak i innych podmiotów wymienionych w art. 4 ust. 3 zd. 2 oraz art. 4 ust. 4 ustawy o sprzedaży konsumenckiej - w pierwszej kolejności należy rozumieć działających w jego imieniu pełnomocników i prokurentów oraz przedstawicieli ustawowych. Ponadto przedstawicielem takim będą, jak się wydaje, osoby (fizyczne, prawne, nieposiadające osobowości prawnej, ale mające zdolność prawną), które składając publiczne zapewnienia, czynią to za zgodą producenta, a tym bardziej jeszcze na jego zlecenie (w związku ze stosunkiem prawnym, jaki łączy je $z$ producentem) $)^{53}$.

Spore wątpliwości budzi tu składanie zapewnień publicznych przez osoby trzecie przy braku zgody po stronie producenta. $Z$ uwagi na potrzebę ochrony interesów konsumentów, rozsądne wydaje się, iż ilekroć producent nie sprzeciwił się działaniu takich osób zaraz po tym, jak powziął o nim wiadomość, a gdy to nie poskutkowało, nie skorzystał bez zbędnej zwłoki $z$ przysługujących mu przeciw takim osobom środków prawnych (celem odwołania przez nie dotychczasowych i zapobieżenia składania przez nie dalszych zapewnień publicznych wbrew jego woli), osoby te należy uważać za jego przedstawicieli. W braku stanowczej reakcji ze strony producenta można by bowiem upatrywać jego dorozumianej zgody na składanie zapewnień publicznych określonej treści; tym bardziej jeszcze wówczas, gdy z poczynienia takich zapewnień będzie mógł on odnieść, nawet tylko potencjalnie, korzyść ekonomiczną.

${ }^{52}$ Zob. sposób redakcji art. 1 ust. 2 lit. d dyrektywy.

${ }^{53}$ Zob. M. Pecyna, op.cit., s. 143; E. Wieczorek, op.cit., s. 50; J. Pisuliński, op.cit., s. 178 oraz J. Jezioro, op.cit., s. 182-183. Por. też S. Grundmann, w: EU Sales, s. 139. 
Mutatis mutandis te same spostrzeżenia pozostają adekwatne w stosunku do przedstawicieli innych podmiotów zrównanych $\mathrm{z}$ mocy art. 4 ust. 4 ustawy o sprzedaży konsumenckiej z osobą producenta, tj.: przedstawiciela importera, dystrybutora, quasi-producenta (producenta nominalnego) oraz najprawdopodobniej quasi-importera i quasi-dystrybutora. Pewne trudności interpretacyjne mogą się wiązać $z$ przedstawicielem sprzedawcy. Mianowicie art. 4 ust. 3 zd. 2 ustawy zdaje się - inaczej niż czyni to art. 2 ust. 2 lit. d dyrektywy - pomijać go w gronie podmiotów mogących składać prawnie relewantne zapewnienia publiczne. Zarówno obowiązek prounijnej wykładni prawa krajowego, jak i sam cel ustawowej regulacji prowadzą jednakże do wniosku przeciwnego.

Resumując, do uznania danego podmiotu za przedstawiciela na gruncie przepisu art. 4 ust. 3 i 4 ustawy o sprzedaży konsumenckiej nie jest niezbędne posiadanie przez ten podmiot umocowania w rozumieniu art. 96 k.c. (wynikającego $z$ ustawy, tzw. przedstawicielstwo ustawowe, albo $z$ czynności prawnej, tzw. pełnomocnictwo). Poza osobami mającymi takie umocowanie również te wszystkie podmioty, które działają za zgodą (ewentualnie za samą tylko wiedzą połączoną z brakiem sprzeciwu) sprzedawcy, producenta, quasi-producenta, importera, quasi-importera, dystrybutora i quasi-dystrybutora towaru, winny być tu uważane za ich przedstawicieli.

\section{Brak odpowiedzialności sprzedawcy}

za publiczne zapewnienie

W myśl art. 5 ustawy o sprzedaży konsumenckiej sprzedawca nie jest związany zapewnieniem publicznym (żeby skorzystać z ustawowego domniemania zgodności towaru konsumpcyjnego $\mathrm{z}$ umową, nie musi dowodzić tego, że towar odpowiada publicznemu zapewnieniu $)^{54}$, jeżeli wykaże przynajmniej jedną $z$ następujących oko-

${ }^{54} \mathrm{Na}$ temat rozkładu ciężaru dowodu w kontekście (nie)zgodności towaru konsumpcyjnego z umową zob. M. Koszowski, Ciężar dowodu w przypadku niezgodności towaru konsumpcyjnego z umowa, „Przegląd Legislacyjny” 2012, nr 4, s. 36-46. 
liczności: a) zapewnienia nie znał ani, oceniając rozsądnie, znać nie mógł; b) zapewnienie nie mogło mieć wpływu na decyzję kupującego o zawarciu umowy; c) treść zapewnienia została sprostowana przed zawarciem umowy. Przy tym brzmienie art. 5 ustawy o sprzedaży konsumenckiej w zasadzie pokrywa się $\mathrm{z}$ treścią art. 2 ust. 4 dyrektywy.

\subsection{Nieznajomość}

Jak zostało w punkcie wyżej nadmienione, sprzedawca, na mocy art. 5 ustawy o sprzedaży konsumenckiej, nie będzie związany zapewnieniem publicznym, jeśli wykaże, że tego zapewnienia nie znał ani, oceniając rozsądnie, znać nie mógł. Co należy jednak od razu zauważyć, możliwość ta nie będzie wchodzić w rachubę w przypadku zapewnień publicznych pochodzących od samego sprzedawcy (osób, za których działania i zaniechania sprzedawca ponosi odpowiedzialność jak za własne zachowania - art. 474 zd. 1 k.c.), a także w przypadku zapewnień publicznych złożonych przez przedstawiciela ustawowego, pełnomocnika i prokurenta sprzedawcy, ilekroć podmioty te działały $\mathrm{w}$ granicach umocowania. Wówczas trzeba bowiem przyjąć - nawet gdy jest to całkowicie kontrfaktyczne - że sprzedawca nie mógł nie wiedzieć o treści publicznego zapewnienia, i w związku z tym nie przysługuje mu prawo do przeprowadzenia $\mathrm{w}$ tym względzie jakiegokolwiek przeciwdowodu ${ }^{55}$.

Poza brakiem posiadania wiedzy o zawartości publicznego zapewnienia w myśl art. 5 ustawy (art. 2 ust. 4 tiret 1 dyrektywy) sprzedawca, by zawartość ta nie była dla niego wiążąca, musi jeszcze wykazać, że oceniając rozsądnie (biorąc rzecz racjonalnie), nie mógł jej znać (być jej świadomym). Przy interpretacji tego przepisu ustawy (dyrektywy) nie jest zasadne odwołanie się do utrwalonego

55 Teza ta nie oznacza jednak, że sprzedawca w ogóle nie posiada możliwości zwolnienia się z odpowiedzialności za zapewnienia publiczne, jakie sam złożył. Choć nie będzie mógł on wykazywać swojej niewiedzy w przedmiocie takich zapewnień, to do wykorzystania zostaną mu dwa inne sposoby, o których wspomina w art. 5 ustawy o sprzedaży konsumenckiej (art. 2 ust. 4 dyrektywy). Tak też J. Pisuliński, op.cit., s. 179; odmiennie wydaje się M. Pecyna, op.cit., s. 147. 
w polskim prawie prywatnym pojęcia należytej staranności, w tym też takiej staranności podwyższonej ze względu na profesjonalny charakter działalności dłużnika ${ }^{56}$. Ustawodawca celowo zrezygnował tu bowiem $z$ miernika, jakim jest dany stopień staranności, na rzecz innego wyznacznika w postaci kryterium rozsądku.

Mianowicie wzmiankowany przepis ustawy (dyrektywy) - jak się wydaje - ma na celu zwolnienie sprzedawcy $z$ ponoszenia odpowiedzialności tylko w sytuacjach wyjątkowych, gdy oczywiste jest, że nie mógł on znać treści danego zapewnienia publicznego bądź $z$ racji tego, iż zapoznanie się $z$ nią było $z$ przyczyn obiektywnych niezmiernie utrudnione, bądź z powodu, iż nie mógł on przypuszczać, że zapewnienie o określonej treści mogło w ogóle zostać złożone. Przy tym jako zasadne jawi się przyjęcie fikcji, że sprzedawca w jak najszerszym zakresie dąży do pełnego zaznajomienia się ze wszystkimi informacjami dotyczącymi towarów konsumpcyjnych, jakie oferuje on $u$ siebie $w$ sprzedaży ${ }^{57}$. W rezultacie sprzedawcy będzie bardzo trudno wykazać w praktyce, że - oceniając rozsądnie - nie mógł się on dowiedzieć o zawartości jakichś publicznych zapewnień. Wydaje się, że to ostatnie będzie możliwie np. w sytuacji, gdy zawierająca tego typu zapewnienia reklama ukazała się wyłącznie w prasie lokalnej w miejscowości znacznie oddalonej od miejsca, gdzie sprzedawca prowadzi działalność handlową, albo gdy zapewnienie publiczne zostało złożone w innym kraju, zwłaszcza pozaeuropejskim ${ }^{58}$. Celem zwolnienia się $z$ odpowiedzialności

${ }^{56}$ Inaczej J. Szczotka, op.cit., s. 65; por. też M. Pecyna, op.cit., s. 148 oraz J. Jezioro, op.cit., s. 186-187.

57 Podobnie, wskazując na istnienie po stronie sprzedawcy powinności dysponowania jak najszerszą wiedzą na temat towarów, jakie znajdują się u niego w sprzedaży, J. Szczotka, op.cit., s. 65, a na tle dyrektywy S. Grundmann, w: EUSales, s. 140. O tym, że „trudno sobie wyobrazić, że sprzedawca - pozostając często w stałych stosunkach handlowych - nie zna oferty dostawcy (producenta czy importera) i związanych z nią akcji marketingowych" mówi też A. Sobczak, Za co sprzedawca odpowiada, Nowa ustawa o sprzedaży konsumenckiej, część 2: Obowiazki sprzedawcy, s. 6.

58 Odnośnie do tego typu przykładów zob. J. Szczotka, op.cit., s. 65-66; I. Wesołowska, op.cit., s. 10; W. Czachórski, A. Brzozowski, M. Safian, E. Skowrońska-Bocian, op.cit., s. 411 oraz J. Pisuliński, op.cit., s. 179 wraz z przypisem nr 593 na tej stronie. 
za zawartość publicznych zapewnień sprzedawca $z$ pewnością nie będzie mógł natomiast powoływać się na to, że tych zapewnień nie znał z powodów „czysto” subiektywnych, takich jak np. choroba, fakt nieposiadania odbiornika radiowo-telewizyjnego czy też brak umiejętności czytania ${ }^{59}$. Niemożność zaznajomienia się $z$ treścią zapewnienia publicznego, $\mathrm{z}$ uwagi na potrzebę ochrony interesów kupujących, musi być bowiem obiektywna i niezależna od osobistych przymiotów osoby będącej sprzedawcą (ten, $z$ racji na zakres podmiotowy stosowania ustawy, występuję tu zawsze w roli profesjonalisty).

Przy tym, jak trafnie wskazuje Pecyna, chwilą rozstrzygającą o możliwości dowiedzenia się przez sprzedawcę o danym zapewnieniu publicznym jest moment, w jakim zawarta została umowa sprzedaży ${ }^{60}$. W razie przyjęcia momentu późniejszego prawo sprzedawcy do sprostowania zapewnienia, o jakim jest mowa w art. 5 in fine ustawy o sprzedaży konsumenckiej, nie mogłoby być bowiem zrealizowane.

\subsection{Brak wpływu na decyzję kupującego}

\section{o zawarciu umowy}

Sprzedawca, aby nie być związany publicznym zapewnieniem, może także wykazać, że nie mogło ono mieć wpływu na decyzję kupu-

59 Za nietrafny należy przy tym uznać pogląd, iż na podstawie art. 5 ustawy o sprzedaży konsumenckiej sprzedawca będzie mógł się zwolnić z odpowiedzialności, jeżeli „reklamując czy polecając produkt opierał się na informacjach dostarczonych od producenta oraz tym, że pomimo tych błędnych zapewnień, kupujący podjął decyzje o zakupie wybranego przez siebie towaru”, wyrażony przez K. Szostak, Ochrona kupujacego $w$ świetle nowych regulacji prawnych, „Radca Prawny” 2003, R. XVI, nr 1 (64), s. 32; por. jednakże S. Grundmann, w: EU Sales, przypis nr 98 na s. 140.

${ }^{60}$ M. Pecyna, op.cit., s. 148; tak też J. Jezioro, op.cit., s. 186. Odmiennie, tj. nie za chwilą zawarcia umowy sprzedaży, lecz wydania towaru, wydaje się być tu J. Szczotka, op.cit., s. 66. W razie jednak obrania takiego rozwiązania również sprostowanie tej treści winno być możliwe aż do momentu wydania towaru, a nie, jak expressis verbis stanowi art. 5 ustawy o sprzedaży konsumenckiej, tylko do chwili zawarcia umowy. 
jącego o zawarciu umowy sprzedaży. Tym razem jednak, jak się wydaje, sprzedawca będzie mógł powołać się zarówno na okoliczności obiektywne, jak i subiektywne ${ }^{61}$. Na pierwszych $z$ nich będą zasadzać się np. twierdzenia wskazujące, że zapewnienie zostało złożone dopiero po dacie zawarcia umowy sprzedaży, że zapewnienie nie zawiera w sobie żadnych treści, jakie mogłyby nakłonić kogokolwiek do dokonania zakupu, tudzież, o czym była już mowa w pkt 3, że treść zapewnienia, oceniona rozsądnie, nie mogła być brana na poważnie, a przez to nie będzie mogła wpłynąć na decyzję o nabyciu danego towaru. Okolicznością mającą przesądzać o braku oddziaływania zapewnienia publicznego na podjęcie przez konsumenta decyzji o zawarciu umowy sprzedaży nie wydaje się natomiast to, iż na rynku dostępny był tylko jeden towar danego rodzaju $^{62}$. Zawartość publicznego zapewnienia mogła bowiem spowodować u konsumenta chęć nabycia towaru, jaki - racjonalnie rzecz biorąc - nie był mu w ogóle do niczego potrzebny (nie rozważałby on nabycia tego towaru, gdyby nie powziął wiadomości o zapewnieniu publicznym na jego temat).

Okoliczności subiektywne to $\mathrm{z}$ kolei takie, jakie dotyczą konkretnego konsumenta, tj. tego, który zawarł daną umowę sprzedaży (nabył dany towar konsumpcyjny). Należy do nich przede wszystkim fakt, że dany konsument, choć miał realną możliwość zapoznania się $z$ treścią zapewnienia, to jednak $z$ jakiś leżących po jego stronie przyczyn w rzeczywistości tej treści nie znał (bo np. nie władał językiem, w którym zapewnienie zostawało wyrażone, nie miał dostępu do środków przekazu, za pomocą których zapewnienie złożono itd.) tudzież, że znając zawartość zapewnienia, on sam nie traktował jej poważnie, mimo iż inni mogli ją tak traktować, zwłaszcza otwarcie negował lub drwił z jej prawdziwości/rzetelności. Wśród okoliczności subiektywnych, na jakie skutecznie może powołać się sprzedawca, nie wydaje się jednak znajdować ta, że przy wyborze towaru dany konsument de facto kierował się ceną,

${ }^{61}$ Por. jednak: J. Jezioro, op.cit., s. 187; M. Pecyna, s. 148-149 i J. Szczotka, s. 66.

${ }^{62}$ Inaczej J. Szczotka, op.cit., s. 66. 
a nie właściwościami (przydatnością do określonych celów), jakimi towar miał się odznaczać według treści zapewnienia ${ }^{63}$.

Przy tym dla oceny tego, czy dane zapewnienie publiczne miało, czy nie miało wpływu na decyzję kupującego o dokonaniu zakupu, decydująca będzie chwila zawarcia umowy. Późniejsze natomiast przemyślenia i spostrzeżenia po stronie konsumenta pozostaną dla tej oceny irrelewantne.

Ogólnie ten sposób zwolnienia się przez sprzedawcę $z$ bycia związanym zawartością publicznych zapewnień jawi się jako najtrudniejszy do zrealizowania w praktyce. To, co miało bądź nie miało wpływu na decyzję danej osoby o nabyciu jakiegoś towaru, zdaje się bowiem bardzo trudne do ustalenia, tym bardziej jeszcze w sytuacji, gdy osoba ta nie jest zainteresowana udzielaniem szczegółowych informacji na temat sowich preferencji i schematów rozumowania. Na niewiele - jak się wydaje - zdadzą się tu też próby odwołania do jakiegoś abstrakcyjnego modelu konsumenta (osoby przeciętnej) ${ }^{64}$. W rezultacie też przeprowadzenie przez sprzedawcę wiarygodnego dowodu w wielu przypadkach będzie mogło okazać się tutaj po prostu niewykonalne ${ }^{65}$. Raz jeszcze warto jednak podkreślić możliwość wiązania wpływu zapewnienia publicznego na decyzję kupującego o nabyciu towaru $z$ wymogiem poddawania zawartości publicznych zapewnień rozsądnej ocenie. Wydaje się bowiem, że dane zapewnienie nie będzie mogło mieć wpływu na taką decyzję, ilekroć, oceniając rozsądnie, nie tylko już nawet wzorcowy, ale i konkretny (faktycznie będący stroną danej umowy) konsument nie dał wiary temu zapewnieniu ${ }^{66}$.

${ }^{63}$ Pogląd przeciwny - tj. że o braku wpływu zapewnienia publicznego na decyzję kupującego o zawarciu umowy może świadczyć fakt, iż ten, wybierając towar, kierował się innym kryterium (np. rozmiarem, a nie energochłonnością) aniżeli to, które było objęte przedmiotem publicznego zapewnienia - zdaje się prezentować J. Szczotka, op.cit., s. 66.

${ }^{64}$ Por. jednak J. Jezioro, op.cit., s. 187; M. Pecyna, op. cit., s. 148-149 i J. Szczotka, op.cit., s. 66.

${ }^{65} \mathrm{Na}$ to, że dowód odnośnie do tego, że jakieś zapewnienie publiczne nie miało wpływu na decyzje kupującego o zawarciu umowy, może być w praktyce niezwykle trudny, zwraca uwagę J. Pisuliński, op.cit., s. 179.

66 Godna rozważenia jest również sytuacja, w której konsument, zdając się na doświadczenie i wiedzę sprzedawcy, udzielił temu ostatniemu pełnomocnic- 
Pomimo drobnych różnic językowych, art. 5 ustawy o sprzedaży konsumenckiej pod względem normatywnym zdaje się w tym miejscu odpowiadać unormowaniu $z$ art. 2 ust. 4 tiret 3 dyrektywy ${ }^{67}$.

\subsection{Sprostowanie}

Najprostszym $z$ wymienionych $\mathrm{w}$ art. 5 ustawy o sprzedaży konsumenckiej sposobów uniknięcia bycia związanym zawartością publicznych zapewnień jest dla sprzedawcy bez wątpienia sposób trzeci, tj. sprostowanie treści zapewnienia przed zawarciem umowy ${ }^{68}$.

\subsubsection{Sposoby}

Wydaje się, że sprostowanie zawartości publicznego zapewnienia może przybrać trzy postacie, tj. polegać na: a) prostym stwierdze-

twa do nabycia (wytypowania) spośród towarów znajdujących się w jego ofercie handlowej towaru najbardziej „odpowiedniego” $z$ punktu widzenia potrzeb tego konsumenta. Wydaje się mianowicie, iż nie można podzielić tu zdania J. Szczotki, iż w przypadku upoważnienia sprzedawcy do dokonania wyboru towaru zapewnienia publiczne dotyczące tak nabytego towaru należy traktować jako niemające wpływu na decyzję kupującego o zakupie towaru (i przez to dla sprzedawcy niewiążące - M. K.); J. Szczotka, op.cit., s. 66. Wszak zawartością takich zapewnień, ilekroć nie pochodzą one od niego samego, może, a nawet powinien - chcąc dokonać optymalnego wyboru - kierować się także działający w imieniu i ze skutkiem dla konsumenta sprzedawca. $Z$ kolei zwolnienie w takich okolicznościach sprzedawcy z odpowiedzialności za zapewnienia publiczne, jakie on sam złożył, ewidentnie godziłoby w interesy kupującego, będąc przy tym jawnie sprzeczne z zasadami współżycia społecznego. Dlatego, jak oceniać, w razie udzielenia sprzedawcy pełnomocnictwa do wytypowania towaru, wpływ zapewnień publicznych na decyzję kupującego o zawarciu umowy, nie wydaje się też bez znaczenia treść stosunku prawnego, z jakiego to pełnomocnictwo wynika lub z którym się ono wiąże (np. umowa nieodpłatnego zlecenia, której przedmiot stanowi zawarcie w imieniu konsumenta transakcji, jaka będzie dla niego najbardziej korzystna).

67 Rozbieżność w brzmieniu art. 5 ustawy o sprzedaży konsumenckiej oraz art. 2 ust. 4 tiret 3 dyrektywy (odpowiednio zwroty: „nie mogło ono mieć wpływu na decyzję kupującego o zawarciu umowy” oraz „nie mogło mieć wpływu na decyzję zakupu towarów konsumpcyjnych”), pod kątem ich odmiennej zawartości normatywnej, rozważa jednak M. Pecyna, op.cit., s. 148-149.

${ }^{68}$ Artykuł 2 ust. 4 tiret 2 dyrektywy mówi tu o udowodnieniu, „że w momencie zawierania umowy oświadczenie zostało skorygowane”. 
niu, że towar nie posiada pewnych właściwości lub nie nadaje się do określonych celów, b) na powiadomieniu kupującego, że towar odznacza się właściwościami lub jest zdatny do celów, które są w oczywisty sposób nie do pogodzenia $z$ celem lub właściwościami, o jakich była mowa w zapewnieniu publicznym, c) na wskazaniu na „nieprawdziwość” któregoś z zapewnień publicznych wraz z przytoczeniem treści tego zapewnienia ${ }^{69}$. Przy tym w dwóch pierwszych przypadkach, jak się wydaje, sprzedawca nie musi wyraźnie zaznaczać, które dokładnie zapewnienie prostuje ${ }^{70}$, a w trzecim podawać miejsca (środka przekazu) i czasu, w jakim prostowane zapewnienie było złożone.

\subsubsection{Uprawnione podmioty}

Ponieważ art. 5 ustawy o sprzedaży konsumenckiej (art. 2 ust. 4 tiret 2 dyrektywy) nie określa wyraźnie, kto może prostować zapewnia publiczne, należy przyjąć, że mogą być to również i inne osoby aniżeli sam tylko sprzedawca, zwłaszcza te, od których mające być przedmiotem prostowania zapewnienie pochodzi ${ }^{71}$. Dość wątpliwa jest jednak możliwość prostowania zapewnień publicznych przez podmioty inne niż te, których zapewnienia publiczne, zgodnie $z$ art. 4 ust. 3 zd. 2 i art. 4 ustawy o sprzedaży konsumenckiej, mogą mieć wpływ na oczekiwania konsumentów względem oferowanych im towarów konsumpcyjnych (a więc przez podmioty niewymienione w pkt 7.1-5 niniejszego artykułu). Jej dopuszczenie mogłoby bowiem naruszać uzasadnione interesy tych konsumentów, którzy z racji „nieautoryzowanego" charakteru sprostowań pochodzących od takich podmiotów, nie traktowaliby tych sprostowań jako „autentycznych".

\subsubsection{Sprostowanie publiczne (ad incertas personas)}

Na tle postanowień ustawy o sprzedaży konsumenckiej i dyrektywy nasuwa się również pytanie o to, czy za prawnie skuteczne należy

69 Zob. też. M. Pecyna, op.cit., s. 149-150.

${ }^{70}$ Inaczej J. Jezioro, op.cit., s. 187.

${ }^{71}$ Podobnie J. Jezioro, op.cit., s. 187, J. Pisuliński, op.cit., przypis nr 594 na s. 179, M. Pecyna, op.cit., s. 149. 
traktować tylko takie sprostowanie zapewnienia publicznego, które było skierowane do konkretnego kupującego, czy też także i takie, którego adresatem jest nieoznaczona liczba osób (tzw. sprostowanie publiczne). Wydaje się, że należy dopuścić oba te sposoby, aczkolwiek możliwość dokonania sprostowania w sposób publiczny winna być uzależniona od spełnienia pewnych dodatkowych wymogów.

Po pierwsze, w sprostowaniu publicznym co do zasady trzeba wskazywać na to, które $z$ poprzednio złożonych zapewnień publicznych stanowi przedmiot prostowania wraz $z$ wyraźnym wyszczególnieniem tej jego treści, której zamierza się zaprzeczyć lub którą planuje się zmienić ${ }^{72}$. Po drugie, nie powinno być możliwości prostowania $\mathrm{w}$ ten sposób zapewnień, które nie zostały jeszcze złożone, a jedynie mogą - przez ten sam lub inny podmiot - zostać poczynione w przyszłości. Po trzecie, medium użyte do sprostowania winno być tu co najmniej równie, jeśli nie bardziej dostępne dla konsumentów co medium wykorzystane do złożenia zapewnienia będącego przedmiotem prostowania (np. zapewnienia wyrażonego w reklamie telewizyjnej nie powinno być wolno prostować $\mathrm{w}$ prasie $)^{73}$. Po czwarte, gdy zapewnienie publiczne było składane kilkakrotnie, również jego publiczne prostowanie winno się odbyć więcej niż tylko jeden raz, a najlepiej taką samą lub większą liczbę razy. Po piąte, jak się wydaje, sprostowanie publiczne, by móc zostać uznane za skuteczne, musi nastąpić w na tyle długim czasie przed chwilą zawarcia przez konsumenta umowy sprzedaży, ażeby, oceniając rozsądnie, można było zakładać, że ten rzeczywiście dowiedział się o dokonaniu sprostowania do czasu zawarcia umowy $^{74}$; chyba że sprzedawca udowodni, że mimo iż sprostowanie o publicznym charakterze miało miejsce w chwili późniejszej, to jednak konsument $\mathrm{w}$ momencie zawierania umowy faktycznie o jego poczynieniu wiedział.

72 M. Pecyna, op.cit., s. 149.

${ }^{73}$ Zob. J. Pisuliński, op.cit., przypis nr 594 na s. 179 oraz J. Jezioro, op.cit., s. 188.

${ }^{74}$ Podobnie wydaje się M. Pecyna, op.cit., s. 150. 


\subsubsection{Moment}

Jak stanowi art. 5 ustawy o sprzedaży konsumenckiej (art. 2 ust. 4 tiret 2 dyrektywy), sprostowanie, by odnieść swój skutek w postaci zwolnienia sprzedawcy z odpowiedzialności za treść publicznego zapewnienia, powinno zostać dokonane przed zawarciem umowy (w momencie jej zawierania). Zasadny wydaje się przy tym pogląd Pecyny, zgodnie $z$ którym za sprostowanie poczynione przed zawarciem umowy można tu uznać tylko takie, które odbyło się w czasie umożliwiającym konsumentowi swobodne podjęcie decyzji w kwestii nabycia towaru ${ }^{75}$. Co więcej, jak już zostało to naznaczone w punkcie powyżej, w przypadku prostowania zapewnienia w sposób publiczny, moment, w jakim nastąpiło sprostowanie, winien na tyle poprzedzać moment zawarcia umowy, ażeby, oceniając rozsądnie, można było przypuszczać, że konsument faktycznie zapoznał się $z$ treścią tak dokonanego sprostowania.

\section{Oczekiwania oparte na naturze (charakterze)}

\section{towaru}

Zagadnienie oczekiwań, jakim powinny odpowiadać towary konsumpcyjne, aby móc domniemywać ich zgodność $z$ umową, poważnie komplikuje sposób, w jaki sformułowany został art. 2 ust. 2 lit. d dyrektywy. Mianowicie, zgodnie $z$ tym przepisem dyrektywy domniemywa się, że towary konsumpcyjne są zgodne $z$ umową, jeżeli „wykazują jakość i wykonanie, które są normalne dla towarów tego samego rodzaju i jakich konsument może racjonalnie oczekiwać, biorąc pod uwagę charakter towarów i wszelkie oświadczenia publiczne na temat szczególnych właściwości towarów, jakie wygłosił na ich temat sprzedawca, producent lub ich przedstawiciel, w szczególności w reklamie lub na etykiecie”. Podkreślony zwrot można by tu bowiem traktować jako samodzielną - odrębną od

${ }^{75}$ Ibidem. Na konieczność występowania po stronie konsumenta realnej możliwości zapoznania się ze sprostowaniem przed zawarciem umowy sprzedaży wskazuje też J. Szczotka, op.cit., s. 66. 
odpowiadania przez towar oczekiwaniom opartym na publicznych zapewnieniach - przesłankę domniemania zgodności towaru konsumpcyjnego $\mathrm{z}$ umową. W komentarzu do poszczególnych zapisów dyrektywy tak też czyni Stefan Grundmann ${ }^{76}$. Przy tym jako jeden z przykładów oczekiwań konsumentów, jakie brać się mają nie $z$ zapewnień publicznych, ale $z$ samego charakteru (natury) towaru, podaje on oczekiwania co do materiału znajdującego się wewnątrz towaru, których źródłem jest jakość materiału użytego na wierzchu tego towaru ${ }^{77}$.

W razie słuszności takiego jak przedstawione wyżej podejścia, ustawa o sprzedaży konsumenckiej - na skutek pominięcia jednej z przesłanek, których spełnienie jest konieczne, by można było domniemywać zgodność towaru konsumpcyjnego $\mathrm{z}$ umową - zawierałaby regulację prawną mniej korzystną dla konsumentów od unormowań przewidzianych w dyrektywie. To z kolei automatycznie świadczyłoby o tym, że dyrektywa nie została do polskiego prawa krajowego w pełni przetransponowana, w związku z czym konieczna jest jak najszybsza interwencja legislacyjna ze strony polskiego ustawodawcy celem dostosowania tego prawa do wymogów prawa Unii Europejskiej. Co przy tym dodatkowo znamienne, bardzo trudno byłoby tu też przeprowadzić prounijną wykładnię art. 4 ust. 3 zd. 2 ustawy o sprzedaży konsumenckiej. Instytucja granic dla tego typu wykładni nie wydaje się bowiem zezwalać na dotworzenie w prawie krajowym zupełnie nowej normy prawnej niemającej żadnego „zaczepienia” w językowym znaczeniu postanowień tego prawa ${ }^{78}$.

${ }^{76}$ Zob. S. Grundmann, w: EU Sales, s. 135-137.

77 Ibidem, s. 136.

78 Na temat prounijnej wykładni prawa krajowego oraz jej granic zob. M. Koszowski, Wykładnia prawa krajowego w zgodzie z prawem Unii Europejskiej po uwzględnieniu zmian spowodowanych wejściem $w$ życie Traktatu z Lizbony, „Studia Prawa Prywatnego” 2012, z. 2, s. 60-70; M. Koszowski, Dwa modele wykładni prounijnej, „Studia Europejskie” 2012, nr 3, s. 93-110 oraz M. Koszowski, Granice prounijnej wykładni prawa krajowego, „Radca Prawny” 2012, nr 130, s. 15D-20D wraz z przywołaną tam literaturą i orzecznictwem Trybunału Sprawiedliwości. Z racji, iż dyrektywa (której implementację stanowi ustawa o sprzedaży konsumenckiej) dotyczy stosunków między jednostkami (a nie jednostką a organem władzy publicznej), nie sposób w jej przypadku byłoby także powołać się na ogólną możliwość wywołania bezpośredniego skutku 


\section{Podsumowanie}

Jedną z przesłanek ustawowego domniemania zgodności towaru konsumpcyjnego $z$ umową stanowi odpowiadanie przez ten towar oczekiwaniom konsumentów opartym na zapewnieniach, jakie zostały złożone publicznie przez sprzedawcę, producenta, osobę, która przez umieszczenie na towarze swojej nazwy, znaku towarowego lub innego oznaczenia odróżniającego podaje się za producenta albo która wprowadza towar konsumpcyjny do obrotu krajowego w zakresie działalności swojego przedsiębiorstwa, tudzież przez przedstawiciela któregoś $\mathrm{z}$ tych podmiotów (tj. osobę działającą za ich zgodą/ewentualnie samą tylko wiedzą). Zapewnienia, o jakich tu mowa, winny być źródłem informacji na temat poszczególnych właściwości i celów, jakie towar konsumpcyjny posiada i do jakich się nadaje; przy czym sam sposób złożenia takich zapewnień (rodzaj użytych środków przekazu) zdaje się pozostawać dowolny. Ważne jest jedynie to, aby dane zapewnienie miało charakter publiczny, czyli, żeby zapoznanie się z jego treścią było możliwe dla nieograniczonego kręgu osób. Choć też z pewnością zapewnienia tego rodzaju nie stanowią oświadczeń woli, zasadne wydaje się korzystanie przy ich wykładni $z$ reguł zawartych $w$ art. $65 \S 1$ k.c.

Oparte na publicznych zapewnieniach oczekiwania względem towarów konsumpcyjnych, jakim towary te mają odpowiadać, by można było domniemywać ich zgodność $z$ umową, winny być oczekiwaniami rozsądnymi („racjonalnymi”). Co do zasady, zawartość takich zapewnień nie może być bowiem przyjmowana przez konsumentów bezkrytycznie, lecz musi zostać poddana $z$ ich strony rozsądnej ocenie. Przy ocenie tej chodzi jednak - jak się wydaje nie o rozsądek konkretnej osoby, tej, która faktycznie nabyła jakiś towar, ale o rozsądek przeciętnego adresata, do którego zapewnienie było skierowane.

Szczególną postacią publicznych zapewnień są przy tym te, jakie zostały wyrażone w reklamie oraz w oznakowaniu towaru. Mianowicie

w wyniku nienależycie lub nieterminowo implementowej przez dane państwo członkowskie dyrektywy. 
w stosunku do treści reklamowych bardziej doniosłą rolę, aniżeli w przypadku innych rodzajów zapewnień publicznych, zdaje się odgrywać wymóg kierowania się przez konsumentów rozsądkiem, podczas gdy w odniesieniu do informacji podanych na towarze (jego opakowaniu, etykiecie), $z$ racji, iż $z$ reguły odznaczają się one wysokim stopniem dookreśloności, wymóg ten będzie w praktyce występował niezmiernie rzadko.

Poza powołaniem się na konieczność poddawania zawartości publicznych zapewnień rozsądnej ocenie, sprzedawca, by nie być związanym treścią zapewnienia publicznego, musi udowodnić albo że tego zapewnienia nie znał i - oceniając rozsądnie - znać nie mógł, albo że nie mogło mieć ono wpływu na decyzje kupującego o zawarciu umowy, albo że przed zawarciem umowy doszło do jego sprostowania. Co znamienne, wydaje się, że do dokonania tego sprostowania uprawniony jest nie tylko sprzedawca, ale także i inne podmioty, zwłaszcza te, które, mając być przedmiotem prostowania, zapewnienie wcześniej złożyły. Co więcej, dopuszczalne zdaje się również - aczkolwiek pod pewnymi warunkami - prostowanie zawartości publicznych zapewnień nie drogą zwrócenia się do ściśle określonej osoby, lecz za pomocą oświadczeń skierowanych do niewymienionej $z$ imienia i nazwiska większej liczby osób (tzw. sprostowanie publiczne).

Ponadto, co trzeba podkreślić, kwestia oczekiwań po stronie konsumentów, jakie mają znaczenie dla zgodności towarów konsumpcyjnych z umową, doznaje poważnych komplikacji wówczas, gdy art. 2 ust. 2 lit. d dyrektywy Parlamentu Europejskiego i Rady nr 1999/44/WE z dnia 25 maja 1999 r. w sprawie niektórych aspektów sprzedaży towarów konsumpcyjnych i związanych $z$ tym gwarancji zostanie zinterpretowany w ten sposób, iż przesłanką domniemania zgodności towaru konsumpcyjnego z umową, jakie przewidziano w tej dyrektywie, jest odpowiadanie przez towary konsumpcyjne nie tylko oczekiwaniom opartym na publicznych zapewnieniach, ale również oczekiwaniom, jakie biorą się z charakteru (natury) takich towarów. Obranie takiej wykładni świadczyłoby bowiem o fakcie nienależytej transpozycji wspominanej dyrektywy do polskiego porządku prawnego, a tym samym wskazywało na „palącą” potrzebę nowelizacji Ustawy z dnia 27 lipca 2002 r. 
o szczególnych warunkach sprzedaży konsumenckiej oraz zmianie Kodeksu cywilnego.

\section{SUMMARY}

Consumers' expectations towards the goods offered to them based upon public statements made by the seller, manufacturer, person purporting to be the manufacturer, importer, distributor, and their representatives

The article touches on the issue of the expectations consumers have towards the goods which are offered to them in the light of the seller's responsibility for the quality of such goods. Specifically, the considerations concern the consumers' expectations which sources are public statements that have been made by the seller as well as the manufacturer, importer and distributor (wholesaler) of a given good, or a person who - by placing his/her name, trade mark or other distinctive sign on a consumer good purports to be them.

To this aim, the survey of the opinions of Polish legal doctrine and thorough analysis of the provisions of the Polish Consumer Sale Act and the directive no. 1999/44/EC of the European Parliament and of the Council of 25 May 1999 on certain aspects of the sale of consumer goods and associated guarantees have been undertaken. In consequence, the reader gains not only the commentary but also an insight into the possible discrepancies between Polish domestic law and the European Union legal regulations.

Keywords: consumer, expectation, public, statement, sale, law. 
